\title{
Nutritional and environmental studies on an ocean-going oil tanker. 1. Thermal environment
}

\author{
K. J. COLLINS, T.P. EDDY, D. E. LEE, and P. G. SWANN \\ MRC Environmental Physiology Unit and Department of Human Nutrition, \\ London School of Hygiene and Tropical Medicine, Keppel Street, \\ London W.C. 1 and the Esso Petroleum Company, Medical Department, \\ Esso House, Victoria Street, London S.W.1
}

Collins, K. J., Eddy, T. P., Lee, D. E., and Swann, P. G. (1971). Brit. J. industr. Med., 28, 237-245. Nutritional and environmental studies on an ocean-going oil tanker. I. Thermal environment. Investigations were made on board a modern, air-conditioned oil tanker (S.S. Esso Newcastle) en route to the Persian Gulf in July to August 1967 in order to study thermal conditions in the working environment, and the nutritional status of the crew, and to examine the interrelationship between climate and nutritional balance. In this introductory paper an account is given of the aims and design of the experiments together with details of the environmental survey.

The voyage round Africa lasted one month, with high ambient temperatures of $37 \cdot 7^{\circ} \mathrm{C}$ dry bulb, $30.8^{\circ} \mathrm{C}$ wet bulb $\left(100 / 87^{\circ} \mathrm{F}\right)$ occurring only on the last few days into and out of the Persian Gulf. Mean accommodation temperature was maintained in the zone of comfort throughout, and at $23.9^{\circ} \mathrm{C}\left(75^{\circ} \mathrm{F}\right)$ Corrected Effective Temperature (CET) in the Gulf. On a previous voyage in a tanker without air-conditioning CETs up to $31.6^{\circ} \mathrm{C}\left(89^{\circ} \mathrm{F}\right)$ had been recorded in the accommodation in the same ambient conditions. With exposure to high solar radiation in the Gulf, the deck officer's cabins and bridge house in the upper superstructure became uncomfortably warm (CET exceeding $\left.26 \cdot 6^{\circ} \mathrm{C}\left(80^{\circ} \mathrm{F}\right)\right)$ and in these temperatures skilled performance is likely to deteriorate.

The main thermal problems in the working environment were associated with the engine and boiler rooms which were consistently 11 to $17^{\circ} \mathrm{C}\left(20\right.$ to $\left.30^{\circ} \mathrm{F}\right)$ higher than ambient temperature. For personnel on watch, the levels of heat stress were high but not intolerable if advantage was taken of the air blowers. Conditions under which emergency or repair tasks were carried out in very hot engine-room spaces were examined and often found to allow only a small margin of safety. Predicted average tolerance times were deduced from the Wet Bulb Globe Temperature (WBGT) scale of heat stress. Additional safeguards in these work situations could include the use of a WBGT meter and self-contained air-conditioned protective clothing, and the provision of air-conditioned cubicles.

The CET and WBGT heat stress indices were compared in a wide range of climates with Predicted 4-hr Sweat Rates (P4SR) from 0.1 to 4.9. The regressions of WBGT on P4SR and CET on P4SR were best fitted by quadratic relationships, but the WBGT regression approximated more closely to linearity under the conditions of the present survey. 
Comparatively few investigations appear to have been made in recent times of the dietary of British merchant seamen. The most detailed information on modern seamen's diets has been obtained by Scandinavian and Japanese workers but their studies, not unexpectedly, show qualitative differences from the scale of provisions laid down by the United Kingdom Merchant Shipping Acts. In British vessels there appears to be little serious possibility of malnutrition due to deficiency, but when ships operate on the long routes to tropical waters the interaction of climatic stress and nutrient balances may bring about changes in dietary requirements. The effects of excessive loss of water-soluble nutrients by sweating and of climate on endogenous heat production and energy exchange could thus have an important bearing on the quality of supplies taken on board.

The need for further information on nutritional balances under conditions of heat stress and with acclimatization to heat is allied to that for comprehensive surveys of environmental conditions in work spaces and accommodation in ocean-going merchant ships. The use of air-conditioning has virtually eliminated the problem of heat stress in the living quarters of fleets operating in the tropics but there still exist major heat hazards in work spaces in, for example, engine and boiler rooms.

By agreement with the Management of Esso Petroleum Company's Marine Department, members of the staff of the London School of Hygiene and Tropical Medicine and Esso Medical Department undertook an investigation of climatic and nutritional conditions on board a modern oil tanker (S.S. Esso Newcastle) during a voyage to the Persian Gulf (July to August 1967). The Esso Newcastle (Fig. 1) is a comparatively new steam turbine tanker of the Esso line laid down in 1962 and specially designed for service on the Suez Canal route from the Middle East.

\section{Aims and design of investigations}

The original plan to study the effects of progressively increasing hot conditions through the Suez Canal had to be abandoned with the closing of the Canal in 1967, but in following the long route round Africa there was the opportunity of a longer interval for basal studies in a temperate climate before arriving in the Persian Gulf. The investigations were carried out by a team consisting of two

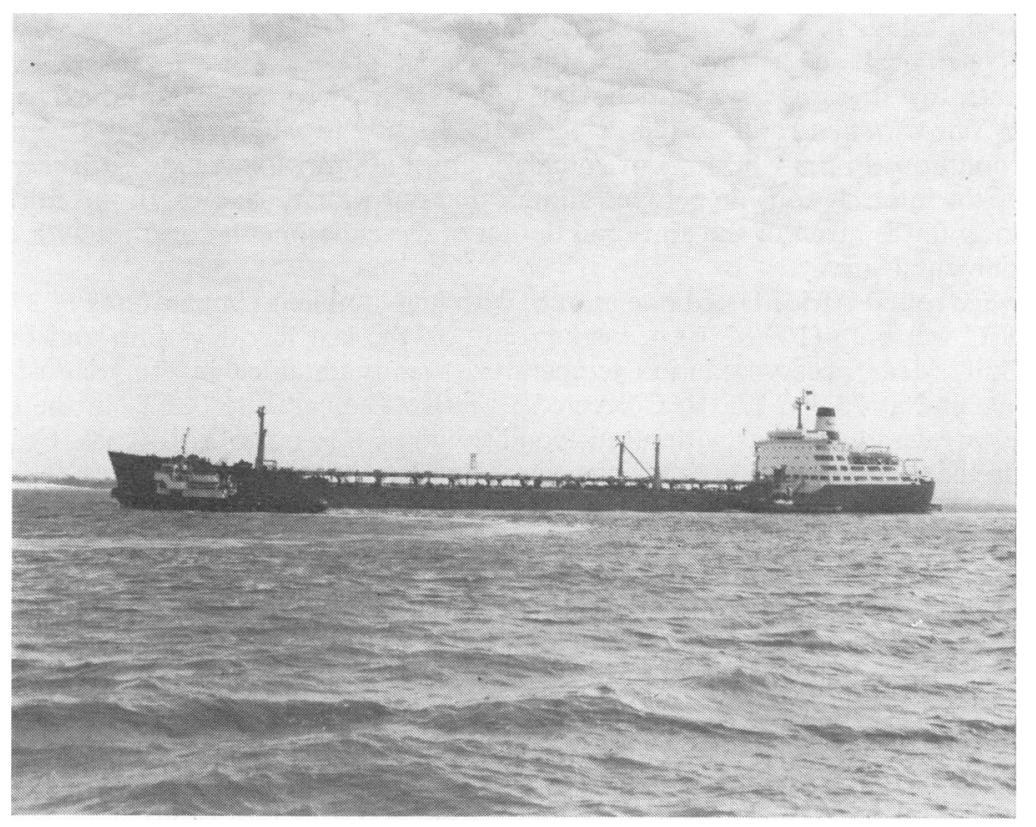

FIG. 1. The S.S. Esso Newcastle (dead weight 51306 tons) has an overall length of $743 \mathrm{ft}(226.5 \mathrm{~m})$, moulded breadth of $102 \mathrm{ft}(31 \cdot 1 \mathrm{~m})$, and a summer draught of $39 \mathrm{ft}(11.9 \mathrm{~m})$. Her engines are geared steam turbine with shaft horsepower 17300 . All accommodation (air-conditioned cabins) is placed aft, giving her an unobstructed upper deck. The complement on the present voyage was 55, which included nine members of the scientific team. (An Esso photograph.) 
environmental physiologists, three nutritionists, a nursing sister, and three medical students who also acted as control subjects and on whom a preliminary nutritional balance study had been carried out one month before departure. The main objectives of the study were threefold:

1. To obtain systematic daily measurements of thermal environmental conditions in accommodation and work spaces and in particular during normal working tasks. In the engine and boiler rooms an assessment of heat tolerance limits would be made by reference to the Wet Bulb Globe Temperature (WBGT) scale of heat stress (Minard, 1964; Bell, Hellon, Hiorns, Nicol, and Provins, 1965). Changes in heat acclimatization during the outward voyage would be investigated in the medical students and three members of the crew by a thermoregulatory function test using controlled hyperthermia equipment (Fox, 1967).

2. Procedures were devised to measure specific metabolic balances, namely, of water, sodium, potassium, nitrogen, and iron on the six subjects during three-day periods at the beginning, in midvoyage, and in hot conditions in the Persian Gulf (Collins, Eddy, Hibbs, Stock, and Wheeler, 1971). A ship's crew offers unique opportunities for practical studies of this kind, for the investigation of intake and excretion in men engaged in normal work in a comparatively small, isolated, and disciplined community, living on ship's stores throughout the voyage, should prove to be easier than with working men living their normal life ashore.

3. A survey of the ship's diet was to be made by measurement of the total weight of food and of each food item consumed on board during a number of days extending from the start to the end of the voyage (Eddy, Stock, and Wheeler, 1971). In addition, it would be possible to obtain an analysis of energy intake and expenditure from detailed studies on the six subjects.

\section{Thermal environment}

In the environmental survey of the ship's compartments, dry bulb, wet bulb, and globe temperatures, air movement (Kata thermometer), and the WBGT heat stress index using a prototype WBGT meter were recorded. The WBGT instrument used on the tanker was a model designed later than that described by Walters (1968), but it did not, as in the more recent version, incorporate direct measurement of air velocity. Measurements were made daily, both a.m. and p.m., on the outward voyage to the Persian Gulf, and a similar but more limited survey was continued on the homeward journey. Mean daily (0800 to $1200 \mathrm{hr}$ ) dry bulb and wet bulb temperatures are plotted in Fig. 2 for three locations: (1) ambient temperatures taken on the bridge wing and aft of the diesel room, (2) accommodation temperatures in 18 different compartments in the living quarters, and (3) engine and boiler room temperatures recorded on the instrument platforms and generator flat. Full details of the daily environmental measurements taken during the survey may be obtained from the Esso Petroleum Company.

\section{Ambient temperatures}

Ambient temperatures on the long route round Africa in July to August 1967 did not exceed $29.4^{\circ} \mathrm{C}\left(85^{\circ} \mathrm{F}\right)$ dry bulb, $25.5^{\circ} \mathrm{C}\left(78^{\circ} \mathrm{F}\right)$ wet bulb, registered in the equatorial region. It was only on the last day of the outward voyage approaching Ras-at-Tannura in the Persian Gulf that truly hot ambient conditions were experienced $\left(36.1{ }^{\circ} \mathrm{C}\right.$ dry bulb, $30^{\circ} \mathrm{C}$ wet bulb $\left(97 / 86^{\circ} \mathrm{F}\right)$ outward journey; $37 \cdot 7^{\circ} \mathrm{C}$ dry bulb, $30 \cdot 8^{\circ} \mathrm{C}$ wet bulb $\left(100 / 88^{\circ} \mathrm{F}\right)$ homeward journey). At this time of the year the approach to the Gulf through the Indian Ocean is rendered relatively cool by the prevailing south-west monsoon. The Esso Newcastle was, in fact, exposed to high ambient temperatures for only four days in the Persian Gulf. Ambient temperatures recorded on the shorter Red Sea route (Fig. 3) show that at least an additional four days of high incident heat load is involved in a single journey through the Red Sea and that the Esso Newcastle would have been exposed to a total of 12 days of high temperatures had she followed that route.

\section{Accommodation temperatures}

Mean accommodation temperature was kept remarkably constant within the range 18.9 to $25^{\circ} \mathrm{C}$ dry bulb, 13.3 to $20.5^{\circ} \mathrm{C}$ wet bulb (66 to $77 / 56$ to $69^{\circ} \mathrm{F}$ ) throughout the voyage (Fig. 2). On the last day of the outward voyage mean accommodation temperature did, however, rise to $27 \cdot 2^{\circ} \mathrm{C}$ dry bulb, $20 \cdot 5^{\circ} \mathrm{C}$ wet bulb $\left(81 / 69^{\circ} \mathrm{F}\right)\left(\right.$ ambient $36.1^{\circ} \mathrm{C}$ dry bulb, $30^{\circ} \mathrm{C}$ wet bulb $\left(97 / 86^{\circ} \mathrm{F}\right)$ ) and at the same position in the Gulf on the homeward voyage the mean temperature was $28.3^{\circ} \mathrm{C}$ dry bulb, $21 \cdot 6^{\circ} \mathrm{C}$ wet bulb $\left(83 / 71^{\circ} \mathrm{F}\right)$ (ambient $37.7^{\circ} \mathrm{C}$ dry bulb, $30.8^{\circ} \mathrm{C}$ wet bulb $\left.\left(100 / 88^{\circ} \mathrm{F}\right)\right)$. The Corrected Effective Temperature (CET) in the accommodation during passage in the Gulf did not exceed $23.9^{\circ} \mathrm{C}\left(75^{\circ} \mathrm{F}\right)$, which implies that the conditions were reasonably comfortable.

Climatic data in a 1953 report to the Esso Medical Department relating to a tanker which was not provided with air-conditioning (Fig. 3) shows that accommodation temperature reached $31.6^{\circ} \mathrm{C}\left(89^{\circ} \mathrm{F}\right)$ CET when the ambient temperature conditions in the Persian Gulf were the same as on the present survey. It is hardly surprising that the report makes reference to common complaints of irritability through lack of sleep, prickly heat, and subacute heat exhaustion. Ellis (1952) concluded that on the mess decks of Royal Navy ships in the tropics the effective temperature should be kept below $25.5^{\circ} \mathrm{C}$ 

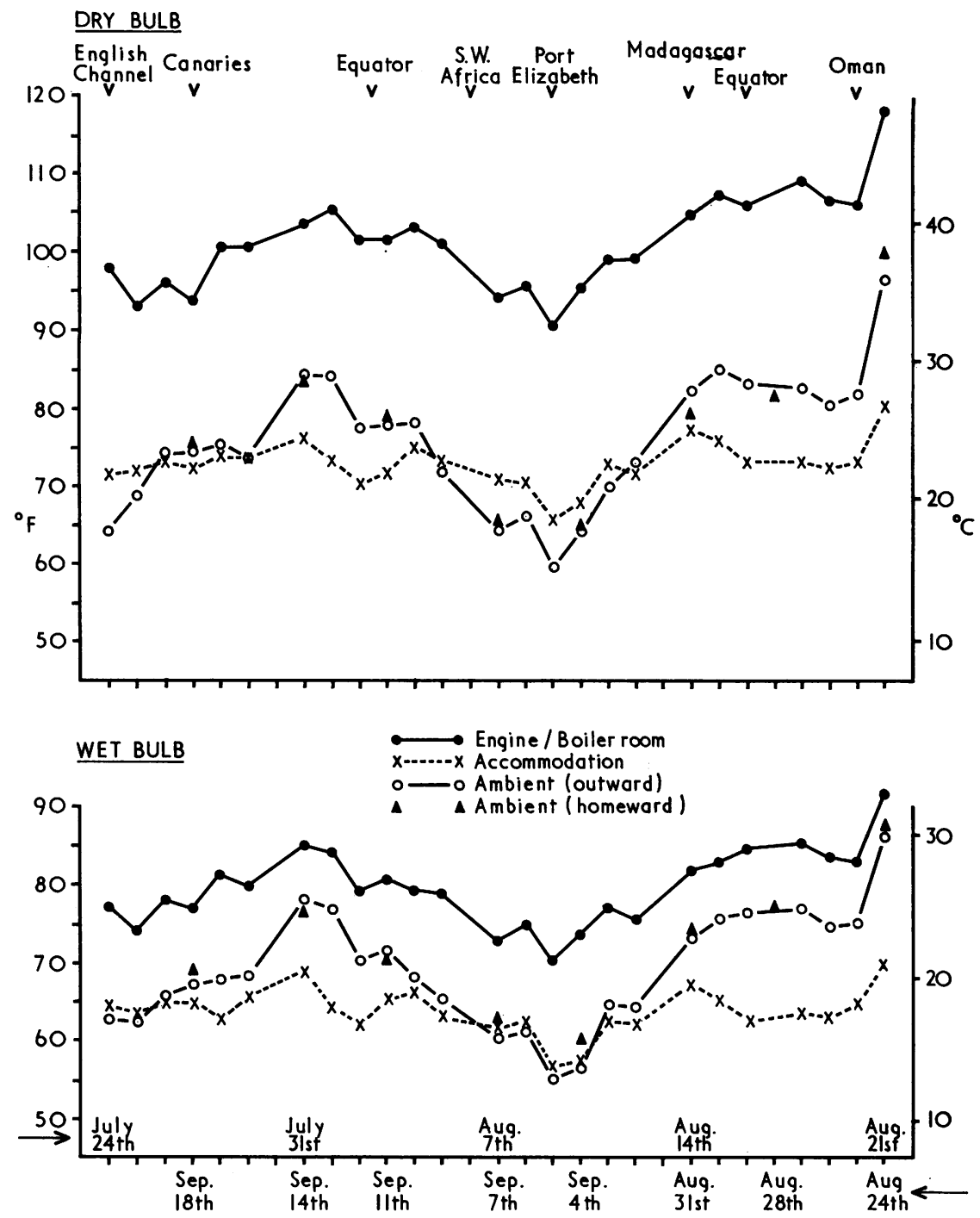

FIG. 2. Mean daily dry bulb and wet bulb temperatures recorded between 0800 and 1200 hr on the Esso Newcastle, July to August 1967.

$\left(78^{\circ} \mathrm{F}\right)$ and that for optimum comfort it should not exceed $23 \cdot 3^{\circ} \mathrm{C}\left(74^{\circ} \mathrm{F}\right)$.

On 21 August in the Gulf, with ambient temperature reaching $35.5^{\circ} \mathrm{C}\left(96^{\circ} \mathrm{F}\right)$ dry bulb, $30^{\circ} \mathrm{C}\left(86^{\circ} \mathrm{F}\right)$ wet bulb on the bridge wing, the heat build up on the deck above the First Officer's cabin (contact thermometer) and inside the cabin was followed during the day. The contact thermometer reading rose from $32.7^{\circ} \mathrm{C}\left(82^{\circ} \mathrm{F}\right)(0900 \mathrm{hr})$ to $69.9^{\circ} \mathrm{C}\left(158^{\circ} \mathrm{F}\right)(1500 \mathrm{hr})$ and cabin temperature from $25.0^{\circ} \mathrm{C}\left(77^{\circ} \mathrm{F}\right)$ dry bulb, $19 \cdot 4^{\circ} \mathrm{C}\left(67^{\circ} \mathrm{F}\right)$ wet bulb $(0900 \mathrm{hr})$ to $30.0^{\circ} \mathrm{C}\left(86^{\circ} \mathrm{F}\right)$ dry bulb, $22 \cdot 8^{\circ} \mathrm{C}\left(73^{\circ} \mathrm{F}\right)$ wet bulb, $26.6^{\circ} \mathrm{C}\left(80^{\circ} \mathrm{F}\right)$
CET $(1800 \mathrm{hr})$. Air movement in the cabin remained at $8 \mathrm{~cm} / \mathrm{s}$, but since air conditioning can cope with only small amounts of radiation, other means such as screening will have to be considered in order to reduce this added thermal load.

\section{Engine/boiler room temperatures}

The main heat problems in the working environment on board were associated with the engine room and boiler room. Mean temperatures in four work spaces in the engine/boiler room (Fig. 2) were 11 to $17^{\circ} \mathrm{C}$ (20 to $30^{\circ} \mathrm{F}$ ) higher in dry bulb and 2.5 to $9{ }^{\circ} \mathrm{C}$ 

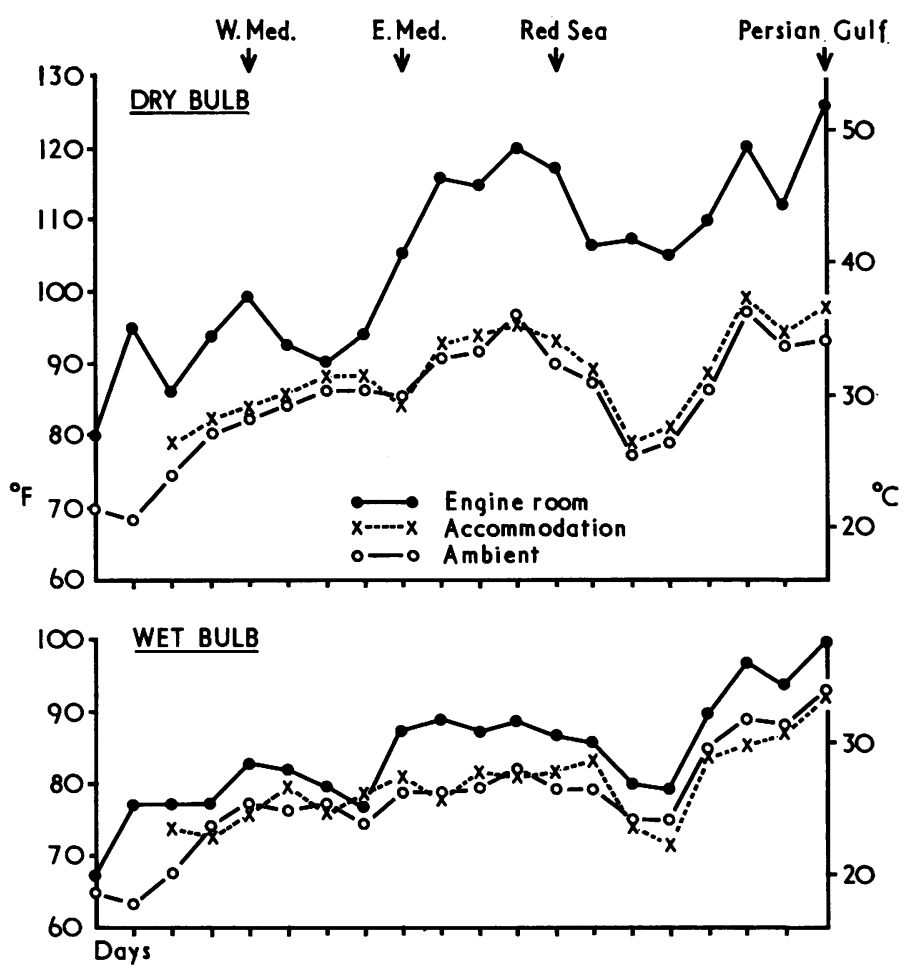

FIG. 3. Daily dry bulb and wet bulb temperatures on S.S. Lucky Star, July to August 1953. From data of Dr. J. de Bary, Esso Medical Department.

( 5 to $17^{\circ} \mathrm{F}$ ) higher in wet bulb than ambient temperature.

It is clear that a considerable measure of relief from the heat in the engine and boiler rooms is available from the air blowers, i.e., during watch on the instrument platforms. The velocity of air movement through the blowers is greater than $500 \mathrm{~cm} / \mathrm{s}$. However, increased air movement is not always beneficial in extremely hot conditions, for when air temperature is above $37.7^{\circ} \mathrm{C}\left(100^{\circ} \mathrm{F}\right)$ and higher than skin temperature there is an increase in convective heat gain. Depending on other factors, such as humidity and work load, convective heat gain could eventually exceed the increased rate of heat loss by evaporation, and a critical air speed could be reached beyond which convective heat gain becomes detrimental. Such conditions could conceivably be reached if the ship were exposed to higher ambient temperatures than on the present voyage or if the temperature of the blower air increased through excess heat picked up in the ducting system. CETs above the value at which the reversal occurs were not attained on the instrument platforms or in other normal work spaces in the engine and boiler rooms, but CETs between 37.7 and $41.5^{\circ} \mathrm{C}\left(100\right.$ and $\left.106^{\circ} \mathrm{F}\right)$ were recorded in other areas in the engine room.

\section{Heat stress in the working environment}

The levels of heat stress to which engine room personnel were subjected are high but not intolerable, particularly as the men are usually well acclimatized and can, during an uneventful watch, take maximum advantage of the blowers. There are occasions, however, when emergency or repair tasks are necessary in very hot spaces in the engine and boiler rooms, and when, as on the present voyage, the men have little time to consider the effects of the added heat load. Some examples will serve to illustrate the nature of these tasks; the corresponding maximum ambient temperature conditions given in the Table are in all cases close to the mean temperature during the period of observation.

(a) The port boiler was closed down at $1600 \mathrm{hr}$ on 27 July for repair and general maintenance inside the boiler. The boiler doors were removed at $0700 \mathrm{hr}$ the next day, and inspection and maintenance of 
the inside of the boiler, gas plate, and between the boiler and outer walls was carried out by pairs of engineers working intermittently during the next $4 \mathrm{hr}$.

(b) The starboard boiler was closed down for emergency repair work at $1600 \mathrm{hr}$ on 30 July. On this occasion the thermal environment was measured in the workshop area at the rear of the boilers. Here, machine work vital to the repair was necessary for periods of up to $30 \mathrm{~min}$ in the presence of a heat build-up (maximum dry bulb $61 \cdot 1^{\circ} \mathrm{C}\left(142^{\circ} \mathrm{F}\right)$; globe $64.8^{\circ} \mathrm{C}\left(148.8^{\circ} \mathrm{F}\right)$ generated from the boilers.

(c) Changing the main feed filter was generally undertaken by two ratings once a fortnight. Observations were made on 15 August. The job took about $1 \frac{1}{4} \mathrm{hr}$ during which time the dry bulb temperature was $50.5^{\circ} \mathrm{C}\left(123^{\circ} \mathrm{F}\right)$, contact temperature of the outer casing of the filter $77.7^{\circ} \mathrm{C}\left(172^{\circ} \mathrm{F}\right)$, and air movement $25 \mathrm{~cm} / \mathrm{s}$. The predicted average tolerance time for men resting in these conditions is just under $1 \frac{1}{2} \mathrm{hr}$ (Table) (Bell et al., 1965).

(d) The main bearing of the forced draught fan was cleaned and regreased on 9 August by two engineers, working during $2 \mathrm{hr}$ with 5-10 min work and intervals of 5-10 min rest. Air movement was $25 \mathrm{~cm} / \mathrm{s}$ and contact temperature of the bearing $73.8^{\circ} \mathrm{C}\left(165^{\circ} \mathrm{F}\right)$. For the temperature conditions recorded during this task (Table) the predicted average tolerance time for men sitting would be $63 \mathrm{~min}$.

(e) Temperatures were recorded during the refitting of a pump fan in the engine room on 17 August. This involved two engineers for $7 \mathrm{hr}$, one of whom worked inside the trunking. As the result of this work, salt losses by sweating alone amounted to $10 \mathrm{~g} \mathrm{NaCl}$ per day. A Fantus test on a 24-hr specimen of urine from one of the ratings gave a value of $3 \mathrm{~g} \mathrm{NaCl} / \mathrm{litre}$. The man was instructed to increase his salt intake as there was the imminent risk of salt-deficiency heat exhaustion.

\section{Indices of heat stress}

For the practical purpose of the environmental survey it was decided to make use of two different indices of heat stress, $(a)$ the CET index which is referable to most previous studies carried out on board ship (Smith, 1955) and remains a reliable scale of warmth for use in moderately hot conditions, and (b) the WBGT index which has more recently been adopted by the Royal Navy and other Services in this country and the United States of America for assessing the severity of the thermal climate in field studies. Theoretically, both the CET and WBGT scales are less accurate than the Predicted $4 \mathrm{hr}$ Sweat Rate Index (P4SR) when used at high levels of heat stress (Leithead and Lind, 1964), but for practical purposes the WBGT index presents a very real advantage at the present time in the form of an instrument (WBGT meter, Light Laboratories, Brighton, Sussex) which provides a direct reading of the index.

The WBGT index is calculated from the expression $0 \cdot 7 t_{w}+0 \cdot 1 t_{a}+0.2 t_{g}$ (Yaglou and Minard, 1956), where $t_{w}$ is wet bulb temperature, $t_{a}$ dry bulb temperature, and $t_{y}$ globe temperature. Thus the index takes into account radiant heat (and air movement) as well as wet bulb temperature (associated with humidity and evaporative heat loss) and dry bulb temperature (and convective heat exchange). The weighting of the WBGT index is therefore to be preferred, in the presence of significant radiation usually present on board ship, to other indices which utilize wet bulb and dry bulb as basic measurements.

A comparison of more than 200 WBGT values observed from meter readings with those calculated from psychrometer and globe temperatures showed that over the range of WBGT values 15 to $48^{\circ} \mathrm{C}$ $\left(60\right.$ to $118^{\circ} \mathrm{F}$ ) there was a highly significant correlation $(r=0.99, P<0.001)$. The same high degree of correlation has also been reported by Walters (1968).

The wide range of temperature conditions surveyed in the working environment on board made it possible to assess the usefulness of the CET and WBGT indices in severely hot climates, i.e., under conditions in which the two indices are generally thought to become less accurate. This was done by relating the two indices to the P4SR scale. From 83 observations in the range of P4SR from 0.1 to 4.9 it was found that the regressions of CET on P4SR and of WBGT on P4SR were better fitted by quadratic than by linear relationships. The sum of squares due to fitting the quadratic terms after the linear terms had been fitted was found to be highly significant in both cases (for CET on P4SR, F = 43.35; and for WBGT on P4SR, $F=17 \cdot 48$; where $F_{0 \cdot 01}(1,80) \bumpeq 7$ ). The $95 \%$ confidence limits for each curve are given in Figure 4. It was found that, under the conditions of the present survey, the CET curve falls away from linearity more sharply than that for WBGT with P4SR values above 2 .

\section{Limits of heat tolerance}

The WBGT readings have been used to predict the 'average' tolerance times for which most men may be expected to work before physiological collapse ensues (Table). 'Safe' tolerance times, obtained from the $95 \%$ confidence limits of an experimental series (Beil et al., 1965), are taken to be $75 \%$ of the average tolerance time. The limits of 'safe' tolerance may be said to provide for all but $5 \%$ of the population and give a valuable indication of the time during which a man may be exposed to a particular set of hot environmental conditions before it becomes necessary to withdraw him. The predictions in the Table are for three activities, working $(280 \mathrm{kcal} / \mathrm{hr}$, light to moderate work), standing, and sitting, and are based 


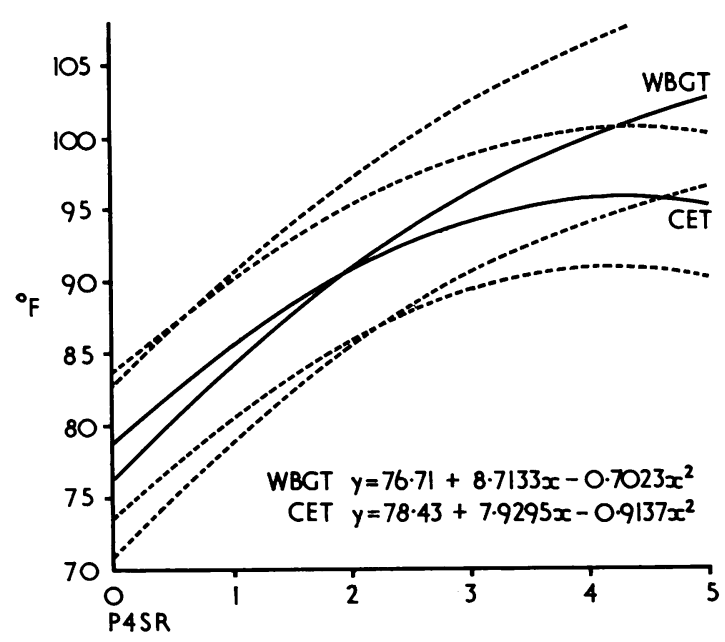

FIG. 4. Quadratic relationships (with $95 \%$ confidence limits) between (1) CET and P4SR and (2) WBGT and P4SR, from temperature observations in various working environments on the Esso Newcastle. on the experimental figures obtained by Bell and his colleagues (1965) on Royal Naval personnel working to the point of imminent collapse in extreme heat. In the experiments of Bell and his colleagues (1965) wall and air temperatures were equal. The predicted tolerance times have therefore been plotted against the WBGT index using the weighting $70 \%$ wet bulb plus $30 \%$ dry bulb temperature (Fig. 5). There was no serious case of heat illness on board during the present survey, but it is obvious from the figures given in the Table that in the Persian Gulf men worked in the engine and boiler rooms under conditions which allow but a small margin of safety when hard physical effort is called for.

\section{Discussion}

The survey of environmental conditions in the Esso Newcastle suggests that one of the major problems on vessels of this type, that of providing comfortable conditions in the accommodation when in tropical waters, has been largely eliminated by adequate air-conditioning. It is realized that our observations were made under 'ideal' conditions

TABLE

Maximum Temperature Conditions in Various Work Spaces with Predicted Average Tolerance Times

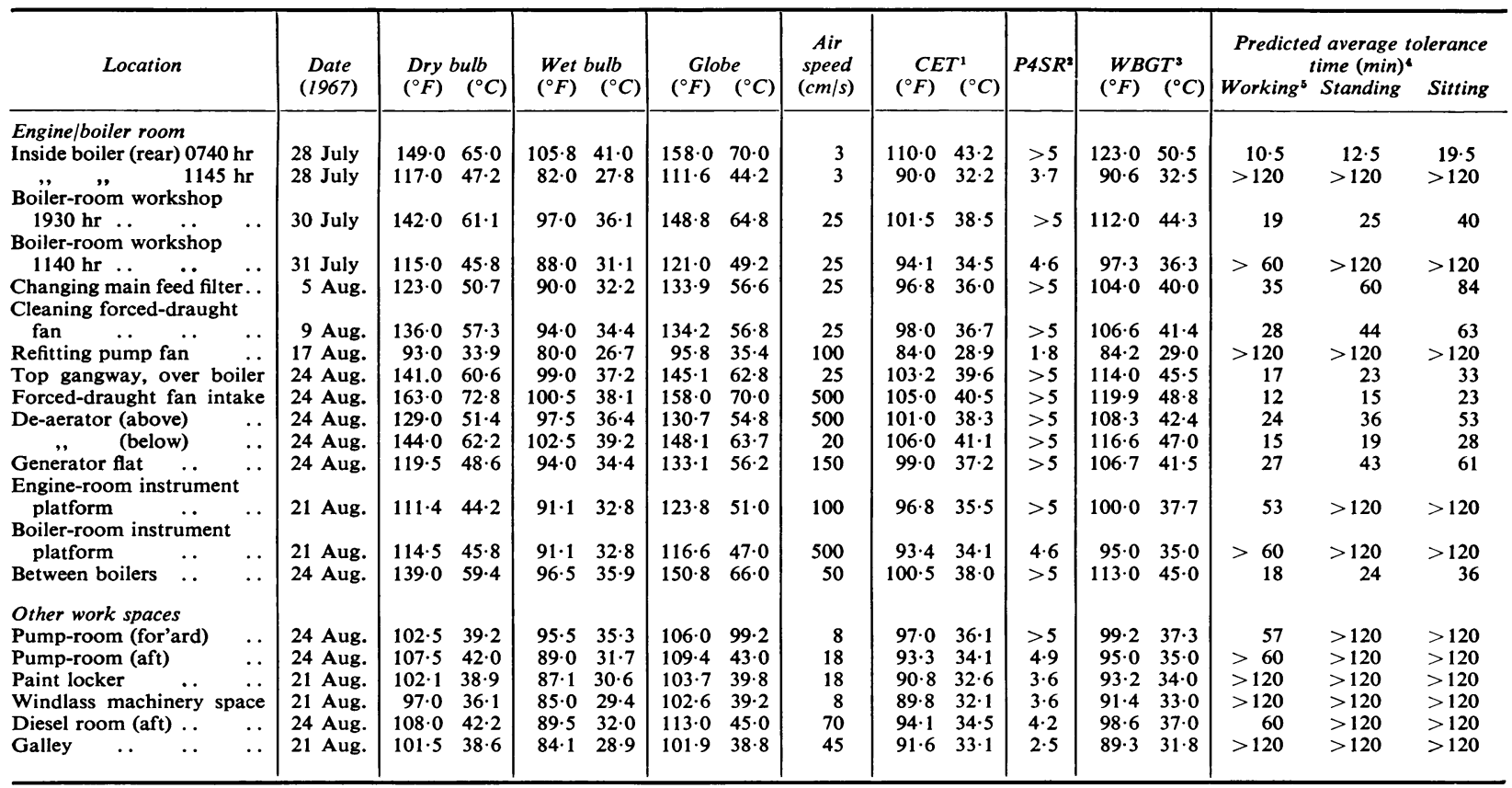

${ }^{1}$ Normal scale of corrected effective temperature; and ${ }^{2}$ Predicted 4-hr sweat rate for men dressed in cotton overalls performing light tasks (175 kcal/hr). 


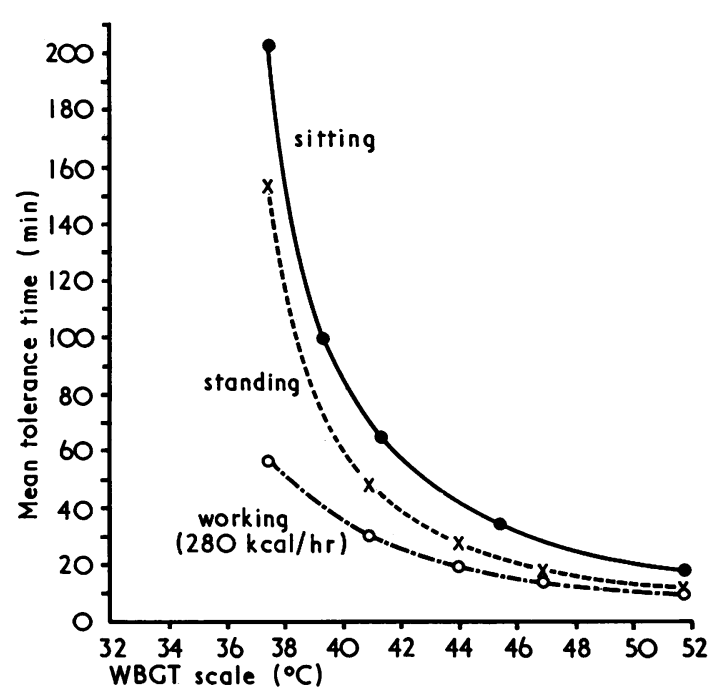

FIG. 5. Predicted average tolerance times based on the WBGT index for partially acclimatized men dressed in cotton boiler-suits. From data of Bell et al. (1965).

since the passage round Africa was cool enough to prevent heat build-up in the ship and the journey into and out of the Persian Gulf was of four days' duration only. There was, unfortunately, no opportunity to test the functioning of the system in ambient temperatures exceeding $37.7^{\circ} \mathrm{C}\left(100^{\circ} \mathrm{F}\right)$ dry bulb or during continuous service in the tropics. In considering the effects of heat on the efficiency and comfort of the crew on the Esso Newcastle there are two aspects which warrant attention. The first concerns the effects of solar radiation on the deckofficers' cabins and bridge house in the upper superstructure; the second, the more serious problem of incipient heat collapse in engine and boiler room personnel.

With high incident radiation in the Gulf, CETs in the deck-officers' cabins were observed to rise above $26.6^{\circ} \mathrm{C}\left(80^{\circ} \mathrm{F}\right)$. Such living conditions are generally uncomfortably warm even for acclimatized men and, if the radiant heat conditions persist for many days, make sleeping difficult and may eventually affect performance. CETs of 29.4 to $31.6^{\circ} \mathrm{C}$ $\left(85\right.$ to $\left.89^{\circ} \mathrm{F}\right)$ were registered in the bridge house above the cabins in the Persian Gulf, an environment in which skilled performance on watch is likely to deteriorate (Pepler, 1958). It is suggested that insulation from solar heat can be improved in several ways, e.g., by awnings erected over the deck above, by whitening the walls and deck surface above the cabins, and by spraying external surfaces with water. The spray technique has been used effectively on Royal Navy aircraft carriers in the
Persian Gulf and it has been found that the accommodation temperature below the flight deck can be reduced by as much as $5 \cdot 5^{\circ} \mathrm{C}\left(10^{\circ} \mathrm{F}\right)$.

In applying the WBGT index to the measure of heat stress and predicting physiological strain, reference may be made to the recommendations of Yaglou and Minard (1957) and Minard (1961) that vigorous training for U.S. Marine Corps recruits be suspended when the WBGT index reaches $29.4^{\circ} \mathrm{C}$ $\left(85^{\circ} \mathrm{F}\right)$ and curtailed for all personnel at $31.1^{\circ} \mathrm{C}$ $\left(88^{\circ} \mathrm{F}\right)$ or above. A marked reduction in the incidence of heat illness over a period of some years has followed the adoption of these recommendations. Apart from the engine and boiler rooms in which WBGTs from 28.9 to $50.5^{\circ} \mathrm{C}$ (84 to $123^{\circ} \mathrm{F}$ ) were recorded, certain work spaces on the Esso Newcastle (Table), namely the paint locker, windlass machinery space, pump rooms, diesel room, and even parts of the galley, registered a WBGT higher than $31^{\circ} \mathrm{C}\left(88^{\circ} \mathrm{F}\right)$ in the Persian Gulf. In hot conditions these areas must be considered potentially hazardous to the well-being of those who are obliged to work for long periods in them.

Smith (1955) concluded that the effective temperature scales underestimate the severity of thermal conditions when dry bulb temperature exceeds $48.8^{\circ} \mathrm{C}\left(120^{\circ} \mathrm{F}\right)$ and when air movement is more than $150 \mathrm{~cm} / \mathrm{s}$. While a number of investigations confirm these observations (Dunham et al., 1946; Lind and Hellon, 1957) there are few data available to assess the accuracy of the WBGT scale in severe conditions. It might be expected that similar limitations apply as the two scales are based on the same basic measurements of globe, wet and dry bulb temperatures. In climates of varying wind speed, temperature, humidity, and radiation, Minard (1964) has shown that the correlations between evaporative sweat loss and CET or WBGT are not significantly different in the range of CET from 25.5 to $31.4^{\circ} \mathrm{C}$ $\left(78\right.$ to $89^{\circ} \mathrm{F}$ ). The present observations suggest that, in relation to P4SR, WBGT diverges less from linearity than CET at high levels of heat stress and may therefore be regarded as a somewhat more accurate index. This may, however hold true only for a particular set of conditions such as in a ship's engine room, approaching the limits of tolerance, in which the humidity is generally low, windspeed varies from 20 to $500 \mathrm{~cm} / \mathrm{s}$, and mean radiant temperature exceeds air temperature.

It is probable that little can be done in existing ships to reduce the overall heat load in the engine and boiler rooms. Personnel working in these spaces do, of course, become heat acclimatized and able to withstand the conditions better than unacclimatized members of the crew. An acclimatized man, taking advantage of the blower, could tolerate a four-hour watch on the instrument platform even in the most severe conditions recorded on the present voyage. 
An unacclimatized man standing in front of the dials of the engine room instrument platform and not immediately under the blower would, however, be limited to a 'safe' tolerance time of only $100 \mathrm{~min}$ in the Persian Gulf. The level of heat stress may rise even further at other locations in the engine and boiler rooms during normal repair and maintenance tasks, to such an extent that even acclimatized men would be physiologically unable to work for anything more than short periods of time.

It is in these extreme situations, especially, that additional safeguards are required. For example, a WBGT meter used in conjunction with the data given in Fig. 5 would provide an immediate indication of the 'average' tolerance time. Improvement in the efficiency and safety with which recurrent tasks are carried out in the engine room in extremely hot (non-toxic) environments could also be achieved by the use of self-contained, air-conditioned clothing, e.g., the Frigivest (North American Distributing Corporation, New York). This system incorporates a simple portable refrigerating device from which cool air is circulated within insulative clothing. Alternative systems of ventilated radiant heat protective clothing, designed primarily for workers in the iron and steel industry (Crockford, $1967,1968)$, are also available. In one respect, however, ventilated suits provided with cool air through an external hose from a fixed compressor suffer a disadvantage in that mobility is limited and a safety hazard is created which is not compatible with work in engine room spaces. A simple Frigivest system consisting of a waist-length jacket with protection for the face and head would allow one man to function for prolonged periods in the most extreme limiting situations encountered in the present survey. The idea of installing air-conditioned cubicles on the instrument platforms has already been considered by the Esso Medical Department. The achievement of a micro-environment even 3.0 to $6.0^{\circ} \mathrm{C}\left(5\right.$ to $\left.10^{\circ} \mathrm{F}\right)$ lower than engine-room temperature in the tropics would undoubtedly provide much-needed relief for engine-room personnel on watch. A potential advantage would be in using the cubicle as a recovery space in the event of heat illness in the lower levels of the engine room, for it was observed that there was no quick route of escape from these areas, and it would be very difficult to manhandle a collapsed patient up ladders to the nearest exit.

The authors are indebted to the Marine Board of Management of the Esso Petroleum Company for providing their full support to these investigations and to the Master, Captain E. R. Gulwell, and crew of the Esso Newcastle for their co-operation and hospitality during the voyage. Environmental data on the Lucky Star (1953) is reproduced in this report by kind permission of Dr. J. de Bary of the Esso Medical Department, Fawley. We should also like to acknowledge the assistance given by Mr. M. J. Crowder with statistical computations.

\section{References}

Bell, C. R., Hellon, R. F., Hiorns, R. W., Nicol, P. B., and Provins, K. A. (1965). Safe exposure of men to severe heat. J. appl. Physiol., 20, 288-292.

Collins, K. J., Eddy, T. P., Hibbs, A., Stock, A. L., and Wheeler, E. F. (1971). Nutritional and environmental studies on an oceangoing oil tanker. 2. Heat acclimatization and nutrient balances. Brit. J. industr. Med., 28, 246-258.

Crockford, G. W. (1967). Heat problems and protective clothing in Iron and Steel works. In The Effects of Abnormal Physical Conditions at Work, edited by C. N. Davies, P. R. Davies, and F. H. Tyrer, pp. 144-156. Livingstone, Edinburgh and London.

(1968). Heat protective clothing. Occup. Hlth, 20, 1-12.

Dunham, W., Holling, H. E., Ladell, W. S. S., McArdle, B., Scott, J. W. Thomson, M. L., and Weiner, J. S. (1946). The effects of air movement in severe heat. Royal Naval Personnel Research Committee, med. Res. Coun. (Lond.), Rep. No. 46/316.

Eddy, T. P., Stock, A. L., and Wheeler, E. F. (1971). Nutritional and environmental studies on an oceangoing oil tanker. 3. Energy balances and physique. Brit. J. industr. Med., in press.

Ellis, F. P. (1952). Thermal comfort in warm, humid atmospheres. Observations in a warship in the tropics. J. Hyg. (Lond.), 50, 415-432.

Fox, R. H. (1967). Further development of the thermoregulatory function test. In Comparative Methodology for Heat Tolerance Testing, edited by A. Henschel, pp. 267-328. U.S. Public Health Service Report TR-44.

Leithead, C. S., and Lind, A. R. (1964). Heat Stress and Heat Disorders, pp. 58-68. Cassell, London.

Lind, A. R., and Hellon, R. F. (1957). Assessment of physiological severity of hot climates. J. appl. Physiol., 11, 35-40.

Minard, D. (1961). Prevention of heat casualties in Marine Corps recruits. Milit. Med., 126, 261-272.

- (1964). Effective Temperature Scale and its Modifications. U.S. Naval Medical Research Institute, Bethesda Research Report No. 6.

Pepler, R. D. (1958). Warmth and performance: an investigation in the tropics. Ergonomics, 2, 63-88.

Smith, F. E. (1955). Indices of heat stress. Med. Res. Coun. (Lond.), Memorandum No. 29.

Walters, J. D. (1968). A field assessment of a prototype meter for measuring the wet-bulb globe-thermometer index. Brit. J. industr. Med., 25, 235-240.

Yaglou, C. P., and Minard, D. (1956). Prevention of Heat Casualties at Marine Corps Training Centres. Office of Naval Research Physiology Branch, Washington, D.C. Final report under Contract No. N 50RI-07665. May 1956.

- - (1957). Control of heat casualties at military training centres. Arch. industr. Hlth, 16, 302-316.

Received for publication August 11, 1970. 